\title{
Antitumor effect of laticifer proteins of Himatanthus drasticus (Mart.) Plumel - Apocynaceae
}

\author{
Kristiana C. Mousinho ${ }^{a}$, Cecília de C. Oliveira ${ }^{a}$, José Roberto de O. Ferreira ${ }^{a}$, Adriana A. Carvalho ${ }^{a}$, \\ Hemerson Iury F. Magalhães ${ }^{a}$, Daniel P. Bezerrab ${ }^{b}$, Ana Paula N.N. Alves ${ }^{d}$, Letícia V. Costa-Lotufo ${ }^{a}$, \\ Claúdia Pessoa ${ }^{\mathrm{a}}$, Mayara Patrícia V. de Matos ${ }^{\mathrm{c}}$, Márcio V. Ramos ${ }^{\mathrm{c}}$, Manoel O. Moraes ${ }^{\mathrm{a}, *}$ \\ a Departamento de Fisiologia e Farmacologia, Faculdade de Medicina, Universidade Federal do Ceará, Fortaleza, Ceará, Brazil \\ ${ }^{\mathrm{b}}$ Departamento de Fisiologia, Universidade Federal de Sergipe, São Cristóvão, Sergipe, Brazil \\ ${ }^{\mathrm{c}}$ Departamento de Bioquímica e Biologia Molecular, Universidade Federal do Ceará, Fortaleza, Ceará, Brazil \\ d Departamento de Clínica Odontológica, Universidade Federal do Ceará, Fortaleza, Ceará, Brazil
}

\section{A R T I C L E I N F O}

\section{Article history:}

Received 22 December 2010

Received in revised form 27 April 2011

Accepted 28 April 2011

Available online 6 June 2011

\section{Keywords:}

Himatanthus drasticus

Apocynaceae

Janaguba

Laticifer proteins

Sarcoma 180

Walker 256 carcinosarcoma

\begin{abstract}
A B S T R A C T
Ethnopharmacological relevance: Himatanthus drasticus (Mart.) Plumel - Apocynaceae is a medicinal plant popularly known as Janaguba. Its bark and latex have been used by the public for cancer treatment, among other medicinal uses. However, there is almost no scientific research report on its medicinal properties. Aim of the study: The aim of this study was to investigate the antitumor effects of Himatanthus drasticus latex proteins (HdLP) in experimental models.

Materials and methods: The in vitro cytotoxic activity of the HdLP was determined on cultured tumor cells. HdLP was also tested for its ability to induce lysis of mouse erythrocytes. In vivo antitumor activity was assessed in two experimental models, Sarcoma 180 and Walker 256 carcinosarcoma. Additionally, its effects on the immunological system were also investigated.

Results: HdLP did not show any significant in vitro cytotoxic effect at experimental exposure levels. When intraperitoneally administered, HdLP was active against both in vivo experimental tumors. However, it was inactive by oral administration. The histopathological analysis indicates that the liver and kidney were only weakly affected by HdLP treatment. It was also demonstrated that HdLP acts as an immunomodulatory agent, increasing the production of OVA-specific antibodies. Additionally, it increased relative spleen weight and the incidence of megakaryocyte colonies.

Conclusion: In summary, HdLP has some interesting anticancer activity that could be associated with its immunostimulating properties.
\end{abstract}

(c) 2011 Published by Elsevier Ireland Ltd.

\section{Introduction}

Himatanthus is a small Apocynaceae genus composed of 14 species (Plumel, 1991). The importance of the genus Himatanthus in traditional medicine is supported by reports where preparations were evaluated for mainly anti-tumor (Bolzani et al., 1999), antiinflammatory (Miranda et al., 2000), anti-ulcerous (Baggio et al.,

Abbreviations: 5-FU, 5-fluorouracil; SBCAL, Sociedade Brasileira de Ciência em Animais de Laboratório; HDLP, Himatanthus drasticus latex protein; MTT, 3-(4,5-dimethyl-2-thiazolyl)-2,5-diphenyl-2H-tetrazolium bromide; OVA, ovabulmin; PBMC, peripheral blood mononuclear cells; TGF- $\beta$, transforming growth factor- $\beta$; TNF- $\alpha$, tumor nuclear factor- $\alpha$.

* Corresponding author at: Departamento de Fisiologia e Farmacologia, UFC, Rua Cel. Nunes de Melo, 1127, 60430-270 Fortaleza, Ceará, Brazil. Tel.: +55 8533668255 ; fax: +558533668333.

E-mail address: odorico@ufc.br (M.O. Moraes).
2005), anti-spasmodic (Rattmann et al., 2005), antimicrobial (Souza et al., 2004), and antileishmanial (Castillo et al., 2007) activities.

Himatanthus drasticus (Mart.) Plumel - Apocynaceae is a medium-sized tree growing on firm ground in South America. It is a medicinal plant popularly known as janaguba, tiboma, jasmimmanga, raivosa, pau-de-leite, joanaguba, and sucuúba (Plumel, 1991). Its bark and latex have been used by the public mainly for cancer treatment, as an anti-inflammatory medication, and to stimulate the immune system (Amaro et al., 2006). Usually, latex plus water (janaguba milk) or decoctions of the bark or latex are taken at a dose of one cup about three times a day. Although several medicinal uses have been described, there are almost no scientific research reports to this regard.

In a preliminary study of the phytochemical and biological effects of Himatanthus drasticus, the ethanolic extract of stem bark was evaluated biologically. This extract was found to be toxic against brine shrimp, but showed no antimicrobial effect 
against the pathogens tested in vitro (Enterobacter, Streptococcus and Escherichia coli). Additionally, it showed antinociceptive (writhing test in rats) affect (Colares et al., 2008). Leite et al. (2009) demonstrated the latex from Himatanthus drasticus to be a cytoprotective agent against ethanol-induced ulcer formation in mice.

The aim of this study was to investigate the antitumor effects of Himatanthus drasticus latex proteins (HdLP) in experimental models. In order to evaluate the toxicological aspects related to HdLP treatment, histopathological and morphological analyses of treated animals were also performed.

\section{Material and methods}

\subsection{Reagents}

5-Fluorouracil (5-FU), O-phenylenidiamine dihydrochloride, Ficoll-Hypaque, phytohemagglutinin, resazurin, and ovalbumin were purchased from Sigma Chemical Co. (St. Louis, MO, USA); rabbit antimouse total Ig (IgG, A, M) was from Serotec (Kidlington, Oxford, UK). All other reagents were of analytical grade.

\subsection{Plant material, latex collection and extraction of Himatanthus drasticus latex proteins (HdLP)}

Latex was obtained in May 2010 from uncultivated plants located in the vicinity of Fortaleza, State of Ceará, Brazil. Botanical material was identified at the Herbarium Prisco Bezerra (Departamento de Biologia, Universidade Federal do Ceará). A voucher was registered under the code 40408.

The latex was obtained after cutting stem and allowing it to flow into tap water in order to give an equal mixture of volumes. The samples were initially centrifuged $(5000 \times g)$ at $10^{\circ} \mathrm{C}$ for $25 \mathrm{~min}$. The pellet was discarded and the soluble phase was dialyzed against distilled water for $60 \mathrm{~h}$ at $25^{\circ} \mathrm{C}$ with water being renewed three times daily. Finally, the dialyzed material was centrifuged as previously done, and clean supernatant was recovered, freeze dried and used in all further determinations. This fraction, comprising almost all soluble latex protein was called HdLP.

\subsection{Animals}

A total of 56 Swiss mice (female, 25-30 g) and 40 Wistar rats (female, 180-220g), obtained from the central animal house of Universidade Federal do Ceará - Brazil, were used. Animals were housed in cages with free access to food and water. All animals were kept under a 12:12 h light-dark cycle (lights on at 6:00 a.m.). Animals were treated according to the ethical principles for animal experimentation of SBCAL (Sociedade Brasileira de Ciência em Animais de Laboratório), Brazil. The Animal Studies Committee of Universidade Federal do Ceará approved the experimental protocol (number 08/08).

\subsection{Cells}

The cytotoxicity of HdLP was tested against HL-60 (leukemia), MDA-MB-435 (melanoma), SF-295 (brain), and HCT-8 (colon) human cancer cell lines, all obtained from the National Cancer Institute, Bethesda, MD, USA. Cells were grown in RPMI-1640 medium supplemented with $10 \%$ fetal bovine serum, $2 \mathrm{mM}$ glutamine, $100 \mu \mathrm{g} / \mathrm{ml}$ streptomycin and $100 \mathrm{U} / \mathrm{ml}$ penicillin, and incubated at $37^{\circ} \mathrm{C}$ with a $5 \% \mathrm{CO}_{2}$ atmosphere.

In order to get healthy human peripheral blood mononuclear cells (PBMC), heparinized blood (from healthy, non-smoker donors who had not taken any drug at least 15 days prior to sampling) was collected, and PBMC were isolated by a standard method of densitygradient centrifugation over Ficoll-Hypaque. PBMC were washed and resuspended. Cells were grown under the same conditions as above plus the addition of phytohemagglutinin (4\%).

Sarcoma 180 tumor cells had been maintained in the peritoneal cavity of Swiss mice and Walker 256 carcinosarcoma tumor cells had been maintained by intramuscular inoculation of the medial side of the thigh of Wistar rats in the Laboratory of Experimental Oncology from the Universidade Federal do Ceará since the mid1980s.

\subsection{In vitro cytotoxic evaluation of $H d L P$}

\subsubsection{Determination of the effect of HdLP on cultured tumor cells}

Tumor cell growth was quantified by the ability of living cells to reduce the yellow dye 3-(4,5-dimethyl-2-thiazolyl)-2,5-diphenyl2H-tetrazolium bromide (MTT) to a purple formazan product (Mossman, 1983). For all experiments, cells were seeded in 96well plates $\left(10^{5}\right.$ cells/well for adherent cells or $0.5 \times 10^{5}$ cells/well for suspended cells in $100 \mu \mathrm{l}$ of medium). After $24 \mathrm{~h}$, the test substance $(0.39-50 \mu \mathrm{g} / \mathrm{ml})$, dissolved in saline, was added to each well (using the HTS-high-throughput screening-Biomek 3000; Beckman Coulter Inc., Fullerton, CA, USA) and incubated for 72 h. 5-FU was used as the positive control. At the end of incubation, the plates were centrifuged and the medium was replaced by fresh medium (150 $\mu \mathrm{l}$ ) containing $0.5 \mathrm{mg} / \mathrm{ml}$ MTT. Three hours later, the formazan product was dissolved in $150 \mu \mathrm{l}$ DMSO and the absorbance was measured using a multiplate reader (DTX 880 Multimode Detector, Beckman Coulter Inc., Fullerton, CA, USA). The drug effect was quantified as the percentage of control absorbance of reduced dye at $595 \mathrm{~nm}$.

PBMC cell growth was determined by the Alamar blue assay (Ahmed et al., 1994). For all experiments, cells were seeded in 96-well plates $\left(0.3 \times 10^{6}\right.$ cells/well for suspended cells in $100 \mu \mathrm{l}$ of medium). After $24 \mathrm{~h}$, the test substance $(0.39-50 \mu \mathrm{g} / \mathrm{ml})$, dissolved in saline, was added to each well (using the HTS - high-throughput screening - Biomek 3000 - Beckman Coulter, Inc., Fullerton, CA, USA) and incubated for $72 \mathrm{~h}$. 5-FU was used as the positive control. Twenty-four hours before the end of incubation, $10 \mu \mathrm{l}$ of stock solution $(0.312 \mathrm{mg} / \mathrm{ml})$ of Alamar Blue (Resazurin) was added to each well. The absorbance was measured using a multiplate reader (DTX 880 Multimode Detector, Beckman Coulter ${ }^{\circledR}$ ) and the drug effect was quantified as the percentage of control absorbance at $570 \mathrm{~nm}$ and $595 \mathrm{~nm}$. The absorbance of Alamar Blue in culture medium is measured at a higher wavelength and lower wavelength. The absorbance of the medium is also measured at the higher and lower wavelengths. The absorbance of the medium alone is subtracted from the absorbance of medium plus Alamar Blue at the higher wavelength. This value is called $\mathrm{AO}_{\mathrm{HW}}$. The absorbance of the medium alone is subtracted from the absorbance of medium plus Alamar Blue at the lower wavelength. This value is called $\mathrm{AO}_{\mathrm{LW}}$. A correction factor $R_{0}$ can be calculated from $\mathrm{AO}_{\mathrm{HW}}$ and $\mathrm{AO}_{\mathrm{LW}}$, where $R_{0}=\mathrm{AO}_{\mathrm{LW}} / \mathrm{AO}_{\mathrm{HW}}$. The percent Alamar Blue reduced is then expressed as follows: \% reduced $=A_{\mathrm{LW}}-\left(A_{\mathrm{HW}} \times R_{0}\right) \times 100$.

\subsubsection{Determination of the effect of HdLP on mouse erythrocytes}

The test was performed in 96 -well plates using a $2 \%$ mouse erythrocyte suspension in $0.85 \% \mathrm{NaCl}$ containing $10 \mathrm{~mm} \mathrm{CaCl}_{2}$, following the method described by Jimenez et al. (2003). HdLP was tested at concentrations ranging from 8 to $200 \mu \mathrm{g} / \mathrm{ml}$. After incubation at room temperature for $30 \mathrm{~min}$ and centrifugation, the supernatant was removed and the hemoglobin released was measured spectrophotometrically as the absorbance at $540 \mathrm{~nm}$. 


\subsection{In vivo antitumor evaluation of $H d L P$}

\subsubsection{Determination of the effect of HdLP on tumor growth in} mice and rats

2.6.1.1. Sarcoma 180 tumor protocol. Ten-day-old Sarcoma 180 ascites tumor cells $\left(2 \times 10^{6}\right.$ cells per $\left.500 \mu \mathrm{l}\right)$ were implanted subcutaneously into the left hind groin of mice (as described by Bezerra et al., 2008). One day after inoculation, HdLP (10 or $20 \mathrm{mg} / \mathrm{kg}$, by intraperitoneal administration; 50 or $100 \mathrm{mg} / \mathrm{kg}$, by oral administration) was dissolved in saline and administered for 7 days.

2.6.1.2. Walker 256 carcinosarcoma tumor protocol. Eight-day-old Walker 256 carcinosarcoma tumor cells $\left(2 \times 10^{6}\right.$ cells per $\left.500 \mu \mathrm{l}\right)$ were implanted subcutaneously into the left hind groin of rats (as described by Moraes et al., 1997). One day after inoculation, HdLP ( 10 or $20 \mathrm{mg} / \mathrm{kg}$, by intraperitoneal administration) was dissolved in saline and administered daily for 7 days.

On day 8 , the animals were sacrificed by cervical dislocation. The tumors, livers, spleens, and kidneys were excised, weighed, and fixed in $10 \%$ formaldehyde. Percent inhibition (\%) was calculated by the following formula: percent inhibition $(\%)=[(A-B) / A] \times 100$, where $A$ is the tumor weight average of the negative control, and $B$ is that of the treated group. Body weights were determined at the start and on the last day of treatment. $5-\mathrm{FU}$ ( $25 \mathrm{mg} / \mathrm{kg} /$ day) was used as the positive control. Negative control was treated with the vehicle used for diluting the test substance (saline).

\subsubsection{Toxicological analyses - histopathology and morphological analyses}

After fixation with formaldehyde, tumors, livers, spleens, and kidneys were grossly examined for size or color changes and hemorrhage. Next, portions of the tumor, liver, spleen, and kidney were cut into small pieces, followed by staining of the histological sections with hematoxylin and eosin. Histological analysis was performed by light microscopy. The presence and extent of liver, kidney or spleen lesions attributed to drugs were determined.

\subsection{Immunomodulatory analyses}

\subsubsection{Subcutaneous immunization}

Two groups of eight Swiss mice were immunized subcutaneously with a single dose of ovabulmin (OVA) $(2 \mathrm{mg} / \mathrm{kg})$ or OVA $(2 \mathrm{mg} / \mathrm{kg}$ ) plus HdLP (40 mg/kg). The mice were bled from the retroorbital plexus to obtain serum samples prior to immunization and at 7, 14 and 21 days after immunization.

\subsubsection{Measurement of specific antibody}

Specific antibodies in serum were detected by enzyme-linked immunosorbent assay (ELISA). In order to evaluate the ability of HdLP to increase the response elicited by OVA, total Ig antibodies against OVA were determined using OVA ( $50 \mu \mathrm{g} /$ well)-coated plates. The plates were incubated at $37^{\circ} \mathrm{C}$ for $1 \mathrm{~h}$ and washed three times with PBS-0.05\% Tween. The plates were blocked with 5\% nonfat milk in $10 \mathrm{mM}$ potassium phosphate buffer, $\mathrm{pH} 7.2$, with $0.9 \%$ $\mathrm{NaCl}$ (PBS) for $2 \mathrm{~h}$ at $37^{\circ} \mathrm{C}$ and washed once, after which $100 \mu \mathrm{l}$ of the appropriate serum diluted in PBS was added and the plates reincubated for $2 \mathrm{~h}$ at $37^{\circ} \mathrm{C}$. The plates were washed again three times with PBS-0.05\% Tween and treated with peroxidase-conjugated rabbit antimouse total immunoglobulins ( $100 \mu \mathrm{l} /$ well, 1:1000 final dilution) for $2 \mathrm{~h}$ at room temperature. The plates were subsequently washed three times with PBS-Tween. The reaction was developed by the addition of orthophenylenediamine followed by incubation for $10 \mathrm{~min}$ at $37^{\circ} \mathrm{C}$. The intensity of the resulting color was read at $450 \mathrm{~nm}$ using a multiplate reader (DTX 880 Multimode Detector, Beckman Coulter Inc., Fullerton, CA, USA).
Table 1

Effect of Himatanthus drasticus latex proteins (HdLP) on human cell lines.

\begin{tabular}{|c|c|c|c|}
\hline Cell line & Histotype & $\operatorname{HdLP~IC~}_{50}(\mu \mathrm{g} / \mathrm{ml})$ & $5-\mathrm{FU} \mathrm{IC} \mathrm{I}_{50}(\mu \mathrm{g} / \mathrm{ml})$ \\
\hline HL-60 & Leukemia & $>50$ & $12.599 .72-16.29$ \\
\hline HCT-8 & Colon & $>50$ & $0.36 \quad 0.18-0.71$ \\
\hline SF295 & Brain & $>50$ & $0.38 \quad 0.23-0.63$ \\
\hline MDA-MB-435 & Melanoma & $>50$ & $1.36 \quad 0.98-1.88$ \\
\hline PBMC & Lymphocytes & $>50$ & $>5$ \\
\hline
\end{tabular}

Data are presented as $\mathrm{IC}_{50}$ values and $95 \%$ confidence interval from three independent experiments, performed in duplicate. 5-Fluorouracil (5-FU) was used as the positive control.

\subsection{Statistical analysis}

Data are presented as mean \pm SEM or $\mathrm{IC}_{50}$ values and their $95 \%$ confidence intervals (CI 95\%) obtained by nonlinear regression. The differences between experimental groups were compared by ANOVA (analysis of variance) followed by Student-Newman-Keuls $(P<0.05)$. All statistical analyses were performed using the GRAPHPAD program (Intuitive Software for Science, San Diego, CA, USA).

\section{Results}

\subsection{In vitro evaluation of HdLP cytotoxicity}

The in vitro effects of HdLP against human tumor cell lines were determined and showed no cytotoxic activity at the tested concentrations (Table 1). 5-FU, used as the positive control, showed $\mathrm{IC}_{50}$ values ranging from 0.36 to $12.59 \mu \mathrm{g} / \mathrm{ml}$ for HCT- 8 and HL-60, respectively.

HdLP was also tested for its ability to induce lysis of mouse erythrocytes. HdLP was not hemolytic even at the highest concentration tested $(200 \mu \mathrm{g} / \mathrm{ml}$, data not shown).

\subsection{In vivo antitumor evaluation of $H d L P$}

The effects of HdLP on mice transplanted with Sarcoma 180 tumor or rats transplanted with Walker 256 carcinosarcoma are presented in Fig. 1. HdLP, given intraperitoneally, was active against both experimental tumors showing a very similar profile. However, it was inactive by oral administration.

In mice inoculated with Sarcoma 180, the average tumor weight of the control was $2.52 \pm 0.14 \mathrm{~g}$ on day 8 . Intraperitoneal HdLP reduced tumor weight to $1.60 \pm 0.18$ and $1.66 \pm 0.18 \mathrm{~g}$ at doses of 10 and $20 \mathrm{mg} / \mathrm{kg} /$ day, respectively (Fig. 1A). These reductions gave inhibition rates of $36.46 \%$ and $34.22 \%$. At $25 \mathrm{mg} / \mathrm{kg} / \mathrm{day}, 5-\mathrm{FU}$ reduced tumor weight by $48.02 \%$ within the same period. Oral HdLP had no effect on tumor weight (data not shown).

In rats inoculated with Walker 256 carcinosarcoma, the average tumor weight of the control was $8.36 \pm 0.55 \mathrm{~g}$ on day 8 . Intraperitoneal HdLP reduced tumor weight to $3.52 \pm 0.94$ and $3.74 \pm 0.95 \mathrm{~g}$ at doses of 10 and $20 \mathrm{mg} / \mathrm{kg} /$ day, respectively (Fig. 1B). These reductions gave inhibition rates of $57.91 \%$ and $55.23 \%$. At $25 \mathrm{mg} / \mathrm{kg} / \mathrm{day}$, 5 -FU reduced tumor weight by $56.34 \%$ within the same period.

Histopathological analysis of the tumors extirpated from Sarcoma 180 control mice or Walker 256 carcinosarcoma control rats showed groups of large, round and polygonal cells, with pleomorphic shapes, hyperchromatic nuclei and binucleation. In the tumors extirpated from treated animals, extensive areas of coagulative necrosis were observed (data not shown).

\subsection{Toxicological analyses}

After treatment with HdLP, no significant changes in the weight of livers or kidneys were seen in mice inoculated with sarcoma 180 or rats inoculated with Walker 256 carcinosarcoma (Table 2). 

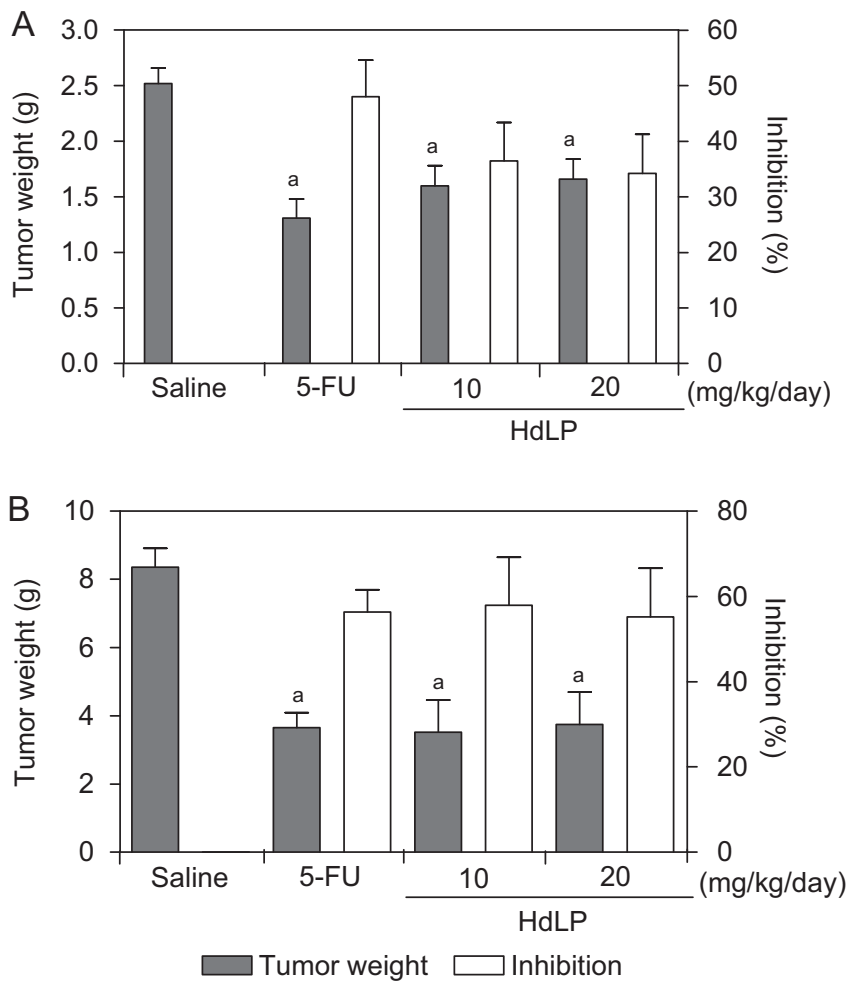

Fig. 1. Effect of Himatanthus drasticus latex proteins (HdLP) on mice transplanted with sarcoma 180 tumor (A) and rats transplanted with Walker 256 carcinosarcoma tumor (B). 5-Fluorouracil (5-FU, $25 \mathrm{mg} / \mathrm{kg} / \mathrm{day}$ ) was used as the positive control. Negative control was treated with the vehicle used for diluting the tested substance (saline). The animals were treated by intraperitoneal administration, starting one day after tumor implantation, for seven consecutive days. Data are presented as mean \pm S.E.M. of eight animals. a $P<0.05$ compared with saline group by ANOVA followed by Student-Newman-Keuls.

However, spleen weights were significantly increased when compared to the control group, in both experimental tumors $(P<0.05)$. Body weight gain was significantly reduced after treatment with $\mathrm{HdLP}(20 \mathrm{mg} / \mathrm{kg} /$ day $)$ or $5-\mathrm{FU}(25 \mathrm{mg} / \mathrm{kg} /$ day $)$ in mice inoculated with sarcoma 180.

Histopathological analyses of kidneys removed from animalstreated with HdLP showed intense swelling of tubular epithelial cells, presence of hyaline cylinder and focal tubular necrosis, but the structure of the glomeruli was essentially preserved (data not shown). In the liver, histopathological analysis showed that animals treated with HdLP had numerous inflammatory foci, intense ballooning degeneration of hepatocytes, microvesicular steatosis, and necrosis (data not shown). In the spleen, HdLP-treated animals showed a discreet increase in megakaryocyte colonies, which suggests an immunomodulatory activity (Fig. 2).

\subsection{Immunomodulatory analyses}

To investigate the effect of HdLP on the induction of humoral immune response in mice immunized with a single dose of OVA ( $2 \mathrm{mg} / \mathrm{kg}$ ) or OVA ( $2 \mathrm{mg} / \mathrm{kg}$ ) plus HdLP ( $40 \mathrm{mg} / \mathrm{kg})$, the OVA-specific antibody levels in serum were measured prior to immunization and at 7, 14 and 21 days after, at a dilution of 1:3200 by ELISA. The results are shown in Fig. 3. HdLP significantly increased the amount of OVA-specific total Ig in the sera of treated animals at the dose of $40 \mathrm{mg} / \mathrm{kg}$ compared to the OVA control $(P<0.05)$.

\section{Discussion}

The present work reports the antitumor effects of HdLP on mice transplanted with Sarcoma 180 and rats transplanted with Walker 256 carcinosarcoma. These models are animal-originated tumors frequently used in in vivo cancer therapy research (Moraes et al., 1997; Lee et al., 2003; Bezerra et al., 2008; Lins et al., 2009; Chen et al., 2010). HdLP inhibited the growth of both experimental tumors, with no effect on cell proliferation in vitro at the concentrations tested. Additionally, its immunoadjuvant activity was also demonstrated. This is the first report describing the antitumor and immunomodulatory properties of HdLP.

HdLP did not show any significant in vitro cytotoxic effect at the experimental exposure levels, but it did show an in vivo antitumor effect. In the preclinical anticancer drug-screening program used in this study, an extract that displayed $\mathrm{IC}_{50}$ values below $30 \mu \mathrm{g} / \mathrm{ml}$ was considered promising (Suffness and Pezzuto, 1990). HdLP showed $\mathrm{IC}_{50}$ values greater than $50 \mu \mathrm{g} / \mathrm{ml}$ for all tumor cell lines tested, suggesting that the in vivo antitumor activity was not related to direct antiproliferative effects.

As previously cited, the ethanolic extract of stem bark of Himatanthus drasticus was active in the brine shrimp lethality test. Its extract showed a highly significant activity in this assay $\left(\mathrm{LC}_{50}=257 \mathrm{ppm}\right)$. The authors attributed these effects to the triterpene lupeol cinammate (Colares et al., 2008). On the other hand, the effect of its latex proteins has never been evaluated against tumor cells lines.

In the genus Himatanthus, the latex of Himatanthus sucuuba is used in its raw form as an antitumor agent (Van der Berg, 1984). Chemical studies have indicated the presence of lupeol acetate,

Table 2

Effect of Himatanthus drasticus latex proteins (HdLP) on organ weights.

\begin{tabular}{|c|c|c|c|c|}
\hline Drug & Dose (mg/kg/day) & Liver ( $g / 100 \mathrm{~g}$ body weight) & Kidney (g/100 g body weight) & Spleen (g/100 g body weight) \\
\hline \multicolumn{5}{|c|}{ Healthy mice } \\
\hline Saline & - & $4.61 \pm 0.19$ & $1.07 \pm 0.03$ & $0.26 \pm 0.02$ \\
\hline \multicolumn{5}{|c|}{ Mice transplanted with S180 } \\
\hline Saline & - & $4.66 \pm 0.06$ & $1.08 \pm 0.02$ & $0,73 \pm 0.02$ \\
\hline 5-FU & 25 & $4.38 \pm 0.09$ & $1.08 \pm 0.04$ & $0.35 \pm 0.05^{\mathrm{a}}$ \\
\hline HdLP & 10 & $4.88 \pm 0.14$ & $1.17 \pm 0.03$ & $1.09 \pm 0.06^{\mathrm{a}}$ \\
\hline HdLP & 20 & $4.97 \pm 0.13$ & $1.19 \pm 0.04$ & $1.10 \pm 0.05^{\mathrm{a}}$ \\
\hline \multicolumn{5}{|c|}{ Healthy rats } \\
\hline Saline & - & $4.54 \pm 0.11$ & $1.01 \pm 0.06$ & $0.50 \pm 0.01$ \\
\hline \multicolumn{5}{|c|}{ Rats transplanted with Walker 256} \\
\hline Saline & - & $4.83 \pm 0.11$ & $0.89 \pm 0.02$ & $0.43 \pm 0.01$ \\
\hline 5-FU & 25 & $4.95 \pm 0.06$ & $1.04 \pm 0.04$ & $0.34 \pm 0.03^{\mathrm{a}}$ \\
\hline HdLP & 10 & $4.84 \pm 0.30$ & $0.88 \pm 0.06$ & $0.50 \pm 0.06$ \\
\hline HdLP & 20 & $5.24 \pm 0.20$ & $0.94 \pm 0.17$ & $0.65 \pm 0.04^{\mathrm{a}}$ \\
\hline
\end{tabular}

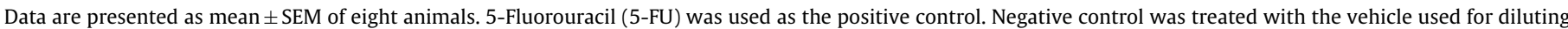
the tested substance (saline). The animals were treated by intraperitoneal administration, starting one day after tumor implantation, for seven consecutive days.

a $P<0.05$ compared with saline group by ANOVA followed by Student-Newman-Keuls. 

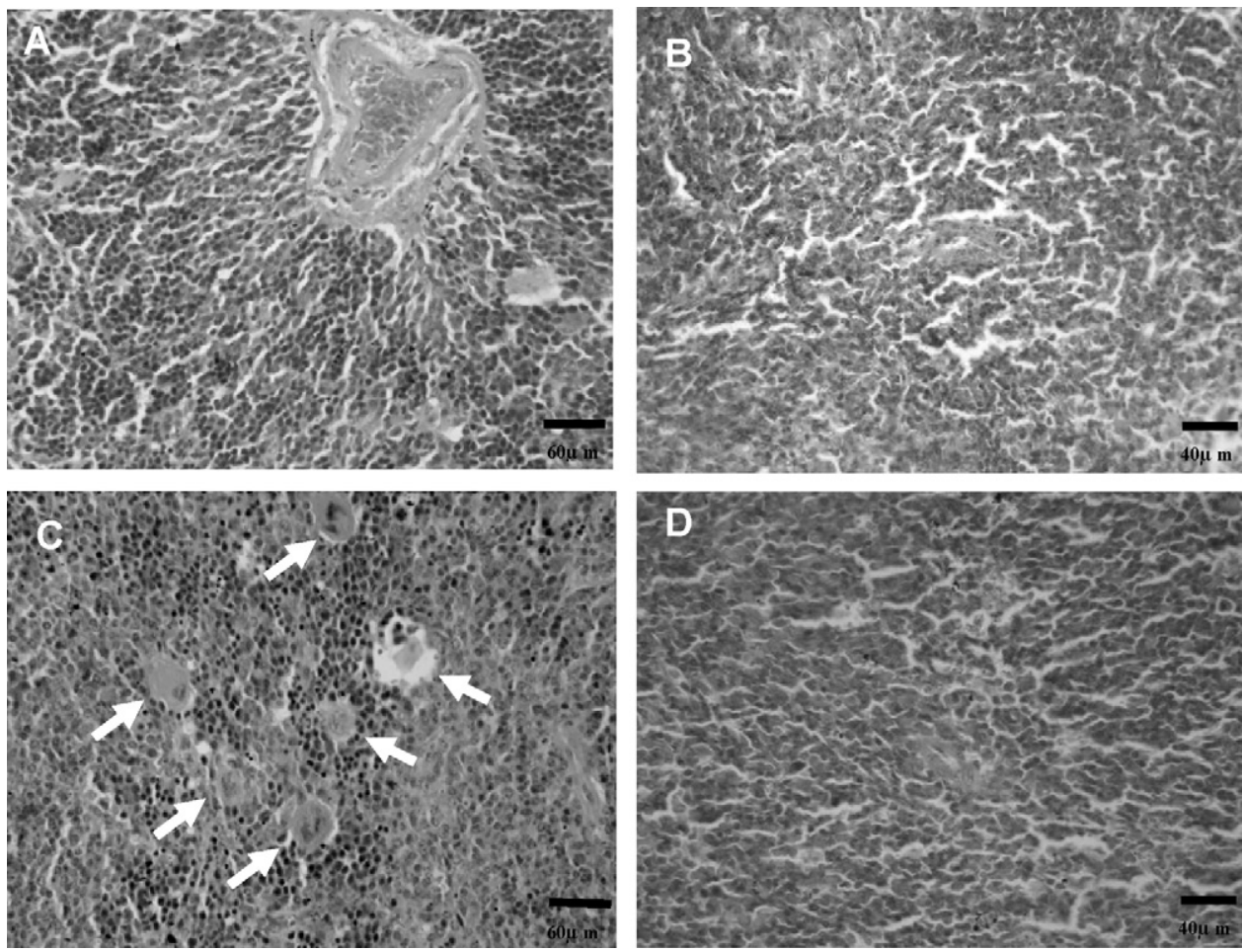

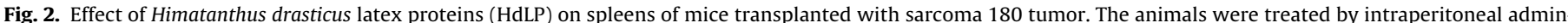

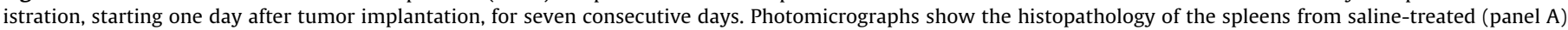

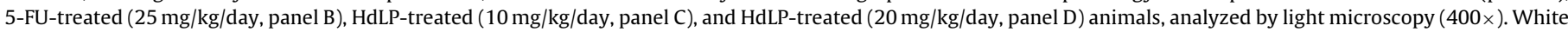
arrow shows megakaryocyte.

alpha-amyrin, and lupeol cinnamates (Miranda et al., 2000). The ethanolic extract of leaves of Himatanthus obovatus showed strong cytotoxic activity in cancer cell lines (Mesquita et al., 2009). Additionally, the ethanolic extract of leaves of Himatanthus attenuatus showed significant toxicity against Artemia salina (Jiménez et al., 2001).In the family Apocynaceae, the laticifer proteins of Calotropis procera (Ait) was shown to exhibit selective cytotoxic effects on human cancer cell lines. It was shown to inhibit DNA synthesis, probably affecting topoisomerase I activity, leading to apoptosis in tumor cells (Oliveira et al., 2007). Recently, its in vivo anticancer potential was also evaluated, reinforcing the potential of laticifer proteins in treating neoplasia (Oliveira et al., 2010).

Furthermore, HdLP acts as an immunomodulatory agent, raising the production of OVA-specific antibodies. Additionally, it was demonstrated that HdLP increased relative spleen weight, and increased megakaryocytic nests, corroborating the hypothesis that it acts through immune stimulation. Thus, these data suggest that the mechanism of beneficial therapeutic effects elicited by HdLP seemed to be attributed to the potentiation of host-defense through the enhancement of immunity, in agreement with its traditional use.

Interestingly, the immunostimulant potential of the genus Himatanthus has been evaluated. The latex of Himatanthus sucu$u b a$ increased nitric oxide (NO) and tumor nuclear factor- $\alpha$ (TNF- $\alpha$ ) and decreased transforming growth factor- $\beta$ (TGF- $\beta$ ) production in macrophages, suggesting an immunomodulatory activity (Soares et al., 2010). In the family Apocynaceae, experimental studies with proteins of the latex of $C$. procera suggested that the active LP fraction (PII) displays in vivo inhibition of tumor growth, probably by mediating an increased immunopharmacological response (Oliveira et al., 2010).

Hepatotoxicity and nephrotoxicity are very common side effects of cancer chemotherapeutic drugs. Hepatic dysfunction induced by vincristine and etoposide (King and Perry, 2001) and renal toxic- ity induced by cisplatin (Pinzani et al., 1994) are such examples. In the present study, the integrity of liver and kidneys in animals subjected to HdLP treatment were evaluated by histopathological analyses.

The liver of HdLP-treated animals showed numerous inflammatory foci, intense ballooning degeneration of hepatocytes, microvesicular steatosis, and necrosis, suggesting intrinsic hepatotoxicity. However, regeneration of hepatic tissues occurs in many diseases. This occurs even when hepatocellular necrosis is present.

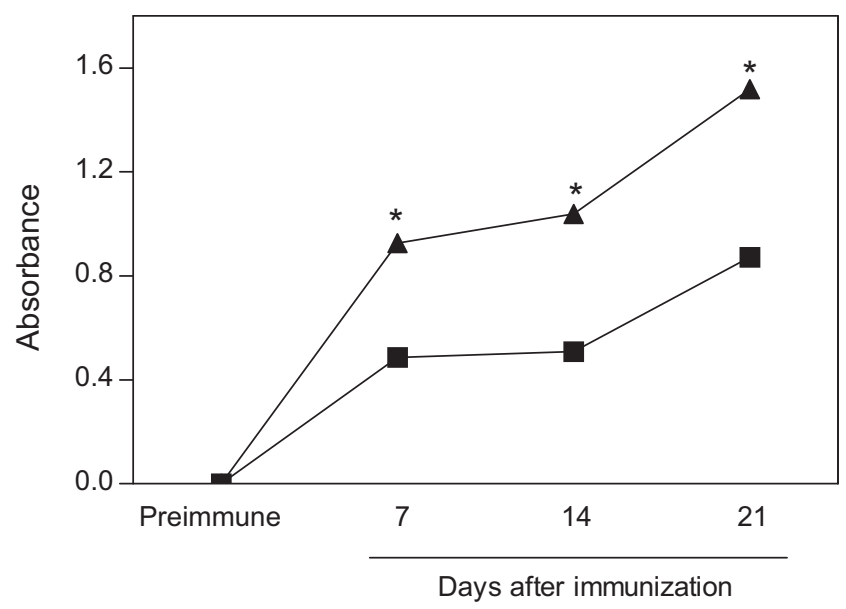

Fig. 3. Effect of Himatanthus drasticus latex proteins (HdLP) on the induction of humoral immune response. Mice were immunized subcutaneously with a single dose of OVA ( $2 \mathrm{mg} / \mathrm{kg}$, $\mathbf{\Delta})$ or with OVA ( $2 \mathrm{mg} / \mathrm{kg}$ ) plus HdLP ( $40 \mathrm{mg} / \mathrm{kg}$, $\mathbf{\square})$, and the production of ovalbumin-specific total Ig antibodies was determined. Sera were collected prior to immunization and 7, 14 and 21 days after immunization. Antibodies were detected by ELISA at a dilution of 1:3200. Data are presented as mean \pm SEM of eight animals. ${ }^{*} P<0.05$, ANOVA followed by Student-Newman-Keuls. 
In hepatic degeneration, regeneration is complete when the connective tissue is preserved (Scheuer and Lefkowitch, 2000; Kummar et al., 2004). The hepatic alterations observed in HdLP-treated animals could be considered reversible (McGee et al., 1992; Scheuer and Lefkowitch, 2000; Kummar et al., 2004).

The kidneys removed from animals-treated with HdLP showed intense swelling of tubular epithelium cell, presence of hyaline cylinder and focal tubular necrosis, but the structure of the glomeruli was essentially preserved. Necrosis of the renal tubule epithelium may often occur as a consequence of the administration of various cancer chemotherapeutic drugs (Olsen and Solez, 1994). It is worth mentioning that the histopathological analyses of HdLP-treated animals demonstrated that the interstitial tissues were preserved, suggesting that regeneration is possible (Curran, 1990; Olsen and Solez, 1994).

In summary, the histopathological analysis indicates that the liver and kidney were only weakly affected by HdLP treatment. Anyway, the HdLP-induced systemic toxicity effect needs to be more extensively evaluated to assess the safety. Then, further studies must be done to well-defined and understand the underline mechanism involved in HdLP toxic effect.

\section{Conclusion}

Briefly, this work showed that HdLP exhibited antitumor effects against experimental tumors without substantial toxicity. In addition, this activity seems to be related to its immunostimulant properties.

\section{Acknowledgments}

The authors are grateful to the Brazilian agencies FINEP, CNPq, BNB/FUNDECI, PRONEX, and CAPES for fellowships and financial support. Silvana França dos Santos provided excellent technical assistance and Dr. A. Leyva helped with English editing of the manuscript.

\section{References}

Ahmed, S.A., Gogal, R.M., Walsh, J.E., 1994. A new rapid and simple non-radioactive assay to monitor and determine the proliferation of lymphocytes: an alternative to $[3 \mathrm{H}]$ thymidine incorporation assay. Journal of Immunological Methods 170, 211-224.

Amaro, M.S., Filho, S.M., Guimarães, R.M., Teófilo, E.M., 2006. Morfologia de frutos, sementes e de plântulas de janaguba (Himatanthus drasticus (Mart.) Plumel Apocynaceae). Revista Brasileira de Sementes 28, 63-71.

Baggio, C.H., Otofuji, G.M., Souza, W.M., Santos, C.A.M., Torres, L.M., Rieck, L., Marques, M.C.A., Mesia-Vela, S., 2005. Gastroprotective mechanisms of indole alkaloids from Himatanthus lancifolius. Planta Medica 71, 733-738.

Bezerra, D.P., Castro, F.O., Alves, A.P., Pessoa, C., Moraes, M.O., Silveira, E.R., Lima, M.A., Elmiro, F.J., Alencar, N.M., Mesquita, R.O., Lima, M.W., Costa-Lotufo, L.V., 2008. In vitro and in vivo antitumor effect of 5-FU combined with piplartine and piperine. Journal of Applied Toxicology 28, 156-163.

Bolzani, V.S., Young, M.C., Furlan, M., Cavalheiro, A.J., Araújo, A.R., Silva, D.H., Lopes, M.N., 1999. Search for antifungal and anticancer compounds from native plant species of Cerrado and Atlantic forest. Anais da Academia Brasileira de Ciências 71, 181-187.

Castillo, D., Arevalo, J., Herrera, F., Ruiz, C., Rojas, R., Rengifo, E., Vaisberg, A., Lock, O., Lemesre, J.L., Gornitzka, H., Sauvain, M., 2007. Spirolactone iridoids might be responsible for the antileishmanial activity of a Peruvian traditional remedy made with Himatanthus sucuuba (Apocynaceae). Journal of Ethnopharmacology 112, 410-414.

Chen, X., Zhang, L., Cheung, P.C., 2010. Immunopotentiation and anti-tumor activity of carboxymethylated-sulfated beta- $(1 \rightarrow 3)$-D-glucan from Poria cocos. International Immunopharmacology 10, 398-405.
Colares, A.V., Cordeiro, L.N., Costa, J.G.M., Silveira, E.R., Campos, A.R., Cardoso, A.H., 2008. Phytochemical and biological preliminary study of Himatanthus drasticus (Mart.) Plumel (Janaguba). Phcognosy Magazine 4, 73-77.

Curran, R.C., 1990. Color Atlas of Histopathology. Oxford University Press, New York.

Jiménez, G., Hasegawa, M., Rodríguez, M., Estrada, O., Méndez, J., Castillo, A., Gonzalez-Mujica, F., Motta, N., Vásquez, J., Romero-Vecchione, E., 2001. Biological screening of plants of the Venezuelan Amazons. Journal of Ethnopharmacology 77, 77-83.

Jimenez, P.C., Fortier, S.C., Lotufo, T.M.C., Pessoa, C., Moraes, M.E.A., Moraes, M.O. Costa-Lotufo, L.V., 2003. Biological activity in extracts of ascidians (Tunicata, Ascidiacea) from the northeastern Brazilian coast. Journal of Experimental Marine Biology and Ecology 287, 93-101.

King, P.D., Perry, M.C., 2001. Hepatotoxicity of chemotherapy. Oncologist 6, $162-176$.

Kummar, V., Abbas, A., Fausto, N., 2004. Robbins and Cotran Pathologic Basis of Disease. W.B. Saunders, China.

Lee, Y.L., Kim, H.J., Lee, M.S., Kim, J.M., Han, J.S., Hong, E.K., Kwon, M.S., Lee, M.J., 2003. Oral administration of Agaricus blazei (H1 strain) inhibited tumor growth in a Sarcoma 180 inoculation model. Experimental Animal 52, 371-375.

Leite, G.D., Penha, A.S., da Silva, G.Q., Colares, A.V., Rodrigues, F.G., Costa, J.G., Cardoso, A.L., Campos, A.R., 2009. Gastroprotective effect of medicinal plants from Chapada do Araripe, Brazil. Journal of Young Pharmacists 1, 54-56.

Lins, K.O., Bezerra, D.P., Alves, A.P., Alencar, N.M., Lima, M.W., Torres, V.M., Farias, W.R., Pessoa, C., de Moraes, M.O., Costa-Lotufo, L.V., 2009. Antitumor properties of a sulfated polysaccharide from the red seaweed Champia feldmannii (DiazPifferer). Journal of Applied Toxicology 29, 20-26.

McGee, J.O.D., Isaacson, P.A., Wright, N.A., 1992. Oxford Textbook of Pathology: Pathology of Systems. Oxford University Press, New York.

Mesquita, M.L., de Paula, J.E., Pessoa, C., de Moraes, M.O., Costa-Lotufo, L.V., Grougnet R., Michel, S., Tillequin, F., Espindola, L.S., 2009. Cytotoxic activity of Brazilian Cerrado plants used in traditional medicine against cancer cell lines. Journal of Ethnopharmacology 123, 439-445.

Miranda, A.L., Silva, J.R., Rezende, C.M., Neves, J.S., Parrini, S.C., Pinheiro, M.L., Cordeiro, M.C., Tamborini, E., Pinto, A.C., 2000. Anti-inflammatory and analgesic activities of the latex containing triterpenes from Himatanthus sucuuba. Planta Medica 66, 284-286.

Moraes, M.O., Fonteles, M.C., Moraes, M.E.A., Machado, I.I., Matos, F.J.A., 1997. Screening for anticancer activity of plants from the Northeast of Brazil. Fitoterapia 68, 235-239.

Mossman, T., 1983. Rapid colorimetric assay for cellular growth and survival: application to proliferation and cytotoxicity assays. Journal of Immunological Methods 65, 55-63.

Oliveira, J.S., Costa-Lotufo, L.V., Bezerra, D.P., Alencar, N.M., Marinho-Filho J.D., Figueiredo, I.S., Moraes, M.O., Pessoa, C., Alves, A.P., Ramos, M.V., 2010. In vivo growth inhibition of sarcoma 180 by latex proteins from Calotropis procera. Naunyn-Schmiedeberg's Archives of Pharmacology 382, 139-149.

Oliveira, J.S., Pereira, D.B., Freitas, C.D.T., Marinho-Filho, J.D.B., Moraes, M.O., Pessoa, C., Costa-Lotufo, L.V., Ramos, M.V., 2007. In vitro cytotoxicity against different human cancer cell lines of laticifer proteins of Calotropis procera (Ait.) R. Br. Toxicology In Vitro 21, 1563-1573.

Olsen, S., Solez, K., 1994. Acute tubular necrosis and toxic renal injury. In: Tisher, C.C. Brenner, B.M. (Eds.), Renal Pathology: With Clinical and Functional Correlations. JB Lippincott Company, Philadelphia, pp. 769-809.

Pinzani, V., Bressolle, F., Haug, I.J., Galtier, M., Blayac, J.P., Balmès, P., 1994. Cisplatininduced renal toxicity and toxicity-modulating strategies: a review. Cancer Chemotherapy and Pharmacology 35, 1-9.

Plumel, M.M., 1991. Le genre Himatanthus (Apocinaceae). Revisión taxonomique: bradea. Boletim do Herbarium Bradeanum 5, 1-20.

Rattmann, Y.D., Terluk, M.R., Souza, W.M., Santos, C.A., Biavatti, M.W., Torres, L.B., Mesia-Vela, S., Rieck, L., da Silva-Santos, J.E., Marques, M.C., 2005. Effects of alkaloids of Himatanthus lancifolius (Muell. Arg.) Woodson, Apocynaceae, on smooth muscle responsiveness. Journal of Ethnopharmacology 100, 268-275.

Scheuer, P.J., Lefkowitch, J.H., 2000. Drugs and toxins. In: Scheuer, PJ, Lefkowitch, JH (Eds.), Liver Biopsy Interpretation. W.B. Saunders, London, pp. 134-150.

Soares, D.C., Andrade, A.L., Delorenzi, J.C., Silva, J.R., Freire-de-Lima, L., Falcão, C.A., Pinto, A.C., Rossi-Bergmann, B., Saraiva, E.M., 2010. Leishmanicidal activity of Himatanthus sucuuba latex against Leishmania amazonensis. Parasitology International 59, 173-177.

Souza, W.M., Stinghen, A.E., Santos, C.A., 2004. Antimicrobial activity of alkaloidal fraction from barks of Himatanthus lancifolius. Fitoterapia 75, 750-753.

Suffness, M., Pezzuto, J.M., 1990. Assays related to cancer drug discovery. In: Hostettmann, K. (Ed.), Methods in Plant Biochemistry: Assays for Bioactivity. Academic Press, London, pp. 71-133.

Van der Berg, M.A., 1984. Ver-o-peso: the ethnobotany of an Amazonian market. In: Prance, G.T., Kallunki, J.A. (Eds.), Advances in Economic Botany 1, Ethnobotany in Neotropics. Bronx, New York, pp. 140-149. 